\title{
Journal of Strategic Security
}

Volume 5

Number 3 Volume 5, No. 3, Fall 2012:

Energy Security

Article 1

\section{Cover \& Front Matter}

Follow this and additional works at: https://digitalcommons.usf.edu/jss

Part of the Defense and Security Studies Commons, National Security Law Commons, and the Portfolio and Security Analysis Commons

pp.

\section{Recommended Citation}

"Cover \& Front Matter." Journal of Strategic Security 5, no. 3 (2012) . Available at: https://digitalcommons.usf.edu/jss/vol5/iss3/1

This Cover \& Front Matter is brought to you for free and open access by the Open Access Journals at Digital Commons @ University of South Florida. It has been accepted for inclusion in Journal of Strategic Security by an authorized editor of Digital Commons @ University of South Florida. For more information, please contact digitalcommons@usf.edu. 
Cover \& Front Matter

This cover \& front matter is available in Journal of Strategic Security: https://digitalcommons.usf.edu/ jss/vol5/iss3/1 


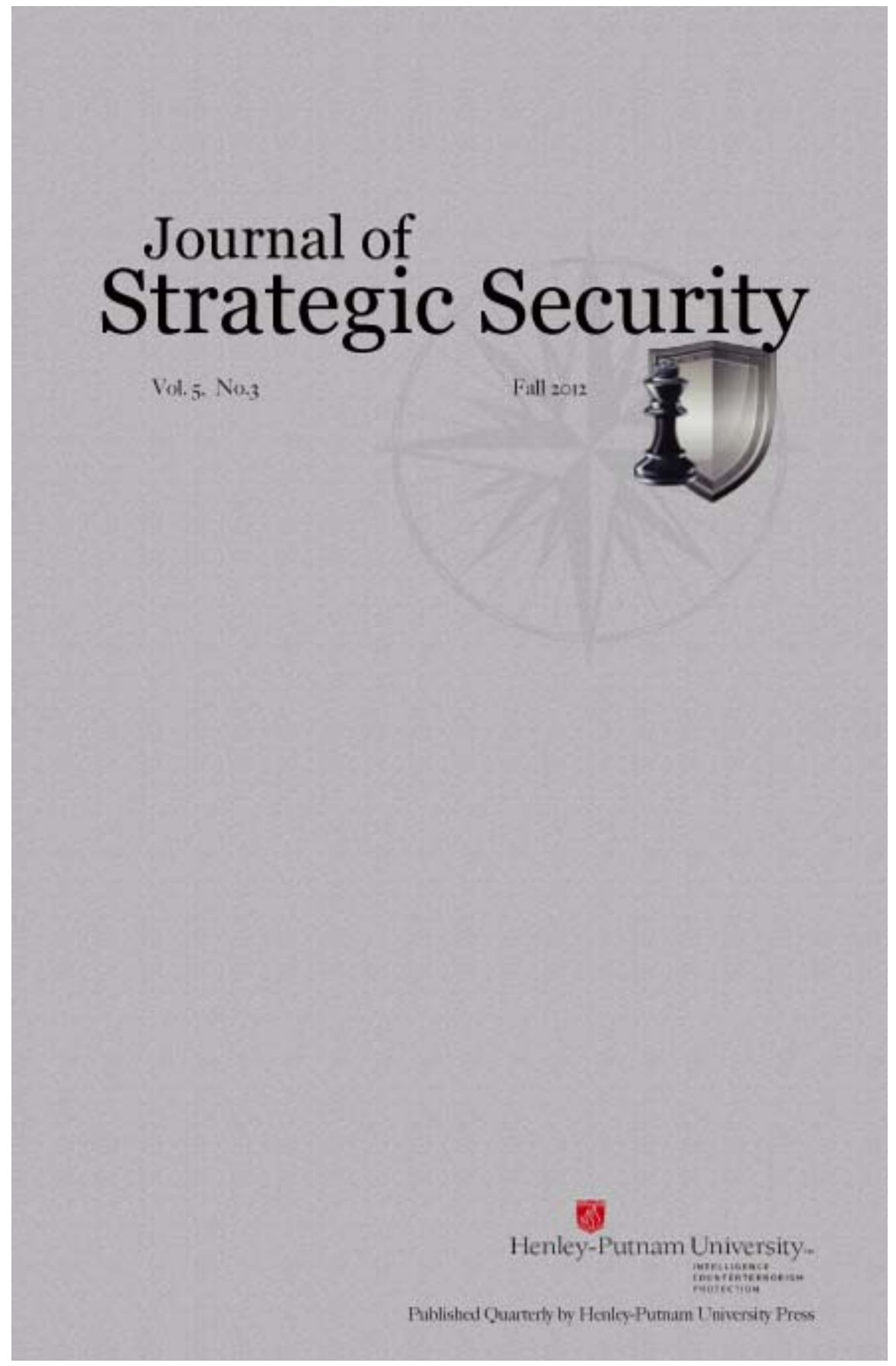


Journal of Strategic Security, Vol. 5, No. 3

https://digitalcommons.usf.edu/jss/vol5/iss3/1 


\title{
JoURNAL OF STRATEGIC SECURITY
}

\author{
Vol. 5, No. 3 Fall 2012
}

\section{Editor-in-Chief}

Jeremy Tamsett, Henley-Putnam University

\section{Senior Editor}

Randy Borum, University of South Florida

\section{Book Review Editor}

Edward J. Hagerty, Henley-Putnam University

\section{Editorial Assistants}

Thomas Cook, Henley-Putnam University

Victor Sundquist, Henley-Putnam University

Thomas Anger, Henley-Putnam University

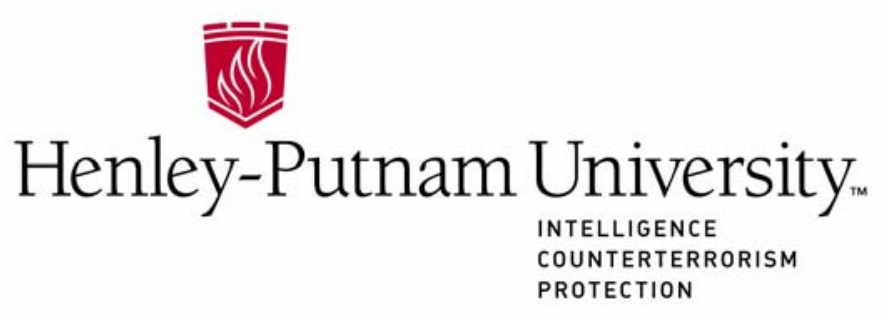

Published Quarterly by

Henley-Putnam University Press

www.henley-putnam.edu 
Copyright (C) 2012 by Henley-Putnam University

All rights reserved. No part of this publication shall be reproduced, stored in a retrieval system, or transmitted by any means electronic, mechanical, photocopying, recording, or otherwise without written permission from the publisher. No patent liability is assumed with respect to the use of the information contained herein. Although every precaution has been taken in the preparation of this publication, the publisher and author(s) assume no responsibility for errors or omissions. Neither is any liability assumed for damages resulting from the use of the information contained herein.

Paperback ISSN: 1944-0464

eBook ISSN: 1944-0472

\section{Warning and Disclaimer}

Every effort has been made to make this publication as complete and as accurate as possible, but no warranty of fitness is implied. The information provided is on an "as is" basis. The authors and the publisher shall have neither liability nor responsibility to any person or entity with respect to any loss or damages arising from the information contained in this publication. 


\section{Editorial Advisory Board}

Gary Ackerman, START Center, University of Maryland

Matt Armstrong, MountainRunner Institute

Edwin Bakker, Security and Conflict Programme, Clingendael Institute

Chris Boucek, Carnegie Endowment for International Peace

Monte Bullard, Henley-Putnam University

Drew Conway, New York University

Sharyl Cross, College of International and Security Studies/George C.

Marshall European Center for Security Studies

Andrea Dew, Center for Irregular Warfare \& Armed Groups, U.S. Naval War College

Christine Fair, Georgetown University

Robert Fein, The Metis Group

James Forest, Center for Combating Terrorism, U.S. Military Academy

Mark Galeotti, Center for Global Affairs, New York University

Sumit Ganguly, Indiana University, Bloomington

Donald Goldstein, Duke University

Colin Gray, University of Reading, England

Denise Greaves, Henley-Putnam University

Sheldon Greaves, Henley-Putnam University

Rita Grossman-Vermaas, Logos Technologies

Audrey Guinchard, University of Essex

John Horgan, International Center for the Study of Terrorism, Pennsylvania State University

Richard J. Hughbank, Northwestern State University

Robert Jervis, Columbia University

Swen Johnson, SCIA, LLC

Richard J. Kilroy Jr., Virginia Military Institute

Steven Kleinman, Consultant

Margaret E. Kosal, Sam Nunn School of International Affairs, Georgia Tech

Claire Metelits, Social Science Research Center, USAFRICOM 
Journal of Strategic Security, Vol. 5, No. 3

Steve Metz, Strategic Studies Institute, U.S. Army War College

Charles A. Morgan, Yale University School of Medicine

John Nagl, Center for a New American Security

David C. Rapoport, University of California at Los Angeles

Mario Scalora, University of Nebraska, Lincoln

Louise Shelly, Terrorism, Transnational Crime \& Corruption Center, George Mason University

Greg Smith, Joint Special Operations Senior Enlisted Academy

John Sullivan, Los Angeles Sheriff's Department

Jessica Turnley, Joint Special Operations University \& Galisteo

Consulting Group

Ed Urie, Henley-Putnam University

Anthony Vinci, The Longare Group 
Correspondence concerning essays submitted for consideration should be directed to: Editor@Henley-Putnam.edu.

Guidelines for manuscript submissions can be found on the Henley-Putnam University website at www.Henley-Putnam.edu. Materials that have been previously published or are under consideration for publication elsewhere will not be accepted.

Questions or correspondence concerning book reviews may be directed to Editor@Henley-Putnam.edu. Unsolicited book reviews will not be accepted.

The Journal of Strategic Security is published quarterly by Henley-Putnam University Press and is an imprint of Happy About (http://happyabout.com, info@happyabout.info or 408-257-300o). 
Journal of Strategic Security, Vol. 5, No. 3 


\section{Table of Contents}

The Strategic Implications

of China's Rare Earths Policy...............................1

Arctic Energy Resources: Security

and Environmental Implications

The 2011 MENA Revolutions:

A Study in U.S. Energy (In)Security ................... 33

European Strategies for Energy

Security in the Natural Gas Market .....................51

Assessing Whether Oil Dependency in

Venezuela Contributes to National Instability .... 69

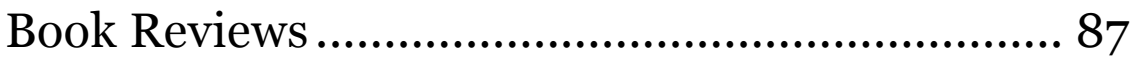

SAS Warlord: Shoot to Kill.................................................. 87

Pakistan on the Brink: The Future of

America, Pakistan, and Afghanistan 
Journal of Strategic Security 